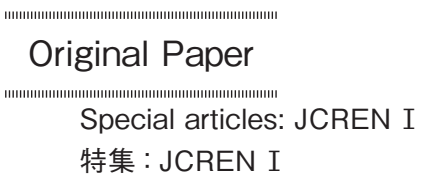

\title{
Methylene Blue Decomposition Via Various In-liquid Plasma Methods
}

\author{
Kazuki TANGE ${ }^{* 1 \dagger}$, Shinfuku NOMURA ${ }^{* 1}$, and Junichi NAKAJIMA $* 1 * 2$ \\ (Received January 6, 2020)
}

\begin{abstract}
At present, the two main wastewater treatment methods are biological treatment and coagulation sedimentation treatment. However, wastewater discharged from dyeing factories cannot be adequately treated because it contains persistent organic substances. The purpose of this study is to develop a treatment for dye wastewater using plasma under atmospheric pressure. The decolorization processing characteristics were investigated using a methylene blue (MB) solution as a model for dye wastewater. The study revealed that an $\mathrm{MB}$ solution could be decolorized using plasma treatment, and the conversion rate was correlated to the MB concentration. The discharge method and liquid temperature affected the conversion of $\mathrm{MB}$, and the conversion rates and energy efficiencies were compared for each condition. Additionally, flow-type plasma that took in air from the side of the reaction vessel could treat $\mathrm{MB}$ the most efficiently and could be stably operated for considerable time. This process may eventually be used to treat dye wastewater discharged from actual dyeing factories.

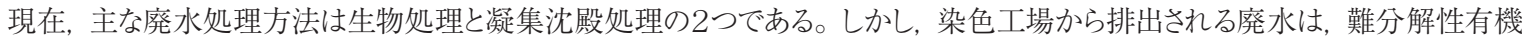
物が含まれているため, 十分に処理することができない。この研究の目的は, 大気圧下でプラズマを用いた染料廃水の処理を開発 することである。メチレンブルー (MB) 溶液を染料廃水のモデルとして使用して, 脱色における処理特性を調査した。この研究によ り, MB 溶液はプラズマ処理を使用して脱色できることがわかり, 変換率は $\mathrm{MB}$ 濃度と相関していた。放電方式と液温が MB の変 換に影響しており，変換率とエネルギー効率を各条件で比較した。反応容器の側面から空気を取り込んだフロー型プラズマは, MB を最も効率よく処理でき，長時間安定して運転できる。このプロセスは，最終的に実際の染色工場から排出される染色廃水を処理 するために使用される可能性がある。
\end{abstract}

\section{Key Words}

Plasma, Water treatment, Methylene blue

\section{Introduction}

In recent years, the problem of colored wastewater has been raised because of a growing interest in environmental issues. Many dyes are carcinogenic and affect the life of aquatic organisms ${ }^{1)}{ }^{2}$. Many textile dyes have high brightness brilliance and intensity of colors and are highly visible even in a very low concentration ${ }^{3}$. Drainage standards are set by Water Pollution Control Law; however, no items in it are related to chromaticity. Therefore, the colored components of wastewater discharged from the textile-dyeing industry are often untreated. Current major wastewater treatment methods comprise biological

※1 Graduate School of Science and Engineering, Ehime University

3, Bunkyo-cho, Matsuyama-shi, Ehime 790-0825, Japan

※2 Environmental and Energy Technology Laboratory Co., Ltd.

$\uparrow$ Corresponding author: tange.kazuki.nz@ehime-u.ac.jp treatment methods using microorganisms and bacteria and coagulation sedimentation methods with the addition of flocculants, which are widely used in Japan. However, dye wastewater discharged from dyeing factories contains persistent organic substances and cannot be sufficiently treated via biological treatments. In addition, water-soluble dyes are difficult to treat using coagulation precipitation methods and sludge is generated.

Various challenges have been made to remove harmful dyes from colored wastewater. Adsorption is one of the simple and inexpensive methods, and various adsorbents have been proposed ${ }^{4) ~}{ }^{6}$. In the advanced oxidation process using ozone, hydrogen peroxide, and ultraviolet rays, harmful substances are decomposed by generating highly reactive $\mathrm{OH}$ radicals ${ }^{7) ~}{ }^{9}$ ). Organic matter decomposed by $\mathrm{OH}$ radicals becomes oxygen and water, so no secondary waste is generated. 
The method for decomposing pollutants using inliquid plasma is attracting attention as a new water treatment method ${ }^{10)} \sim 13$. Hydroxyl radicals generated via underwater discharge have a very strong oxidizing power and can decompose various organic substances ${ }^{14) ~} \sim 18$. Conventional wastewater treatment using $\mathrm{OH}$ radicals is an accelerated oxidation water treatment method; however, hydrogen peroxide is required and has a problem of high operating costs. In the plasma method, active species such as $\mathrm{OH}$ radicals are generated via the decomposition of water, which may lead to a considerable cost reduction.

In this study, we investigated the treatment characteristics in the decolorization of a methylene blue (MB) solution for the purpose of treating dye wastewater with plasma. The most suitable treatment method was determined by comparing the conversion rates and energy efficiencies of three different discharge methods.

\section{Experimental Procedures}

$\mathrm{MB}$ is a kind of basic dye and is a stable substance having a phenothiazine structure. Due to its stability and low toxicity, it has been used by many researchers for degradation evaluation. For the above reasons, MB was used as the dye model in this study. A mixed solution of 10 $\mathrm{mg}$ of MB, $100 \mathrm{mg}$ of sodium sulfate, and $999.9 \mathrm{~g}$ of pure water was used as a model for dyeing discharge water. MPP04-A4-200 (KURITA Manufactory) was used as the power supply for generating plasma, and the frequency was set to $200 \mathrm{kHz}$. The input power was adjusted by changing the pulse width.

Schematics of the experimental apparatuses are shown in Fig. 1. Polycarbonate container with an interior diameter of $55 \mathrm{~mm}$, an exterior diameter of $60 \mathrm{~mm}$ and a height of $90 \mathrm{~mm}$ was used in the reactor of (a) and (b). The reactor of (c) was created by processing a $70 \mathrm{~cm}$ diameter Teflon rod. In all the discharge methods, the electrodes were of $\varphi 3 \mathrm{~mm}$ tungsten, and the distance between the electrodes was $5 \mathrm{~mm}$ for in-liquid plasma and $1 \mathrm{~mm}$ for flow plasma. The solution was refluxed with a cooling apparatus in the case of (a). Conversely, the solution was cooled and circulated in the case of (b). When the in-liquid plasma method is used, a part of input energy is consumed for increasing the water temperature. Energy recovery by introducing a heat exchanger can be considered as a method of improving overall energy efficiency. However, it is necessary to consider the negative effects of methylene
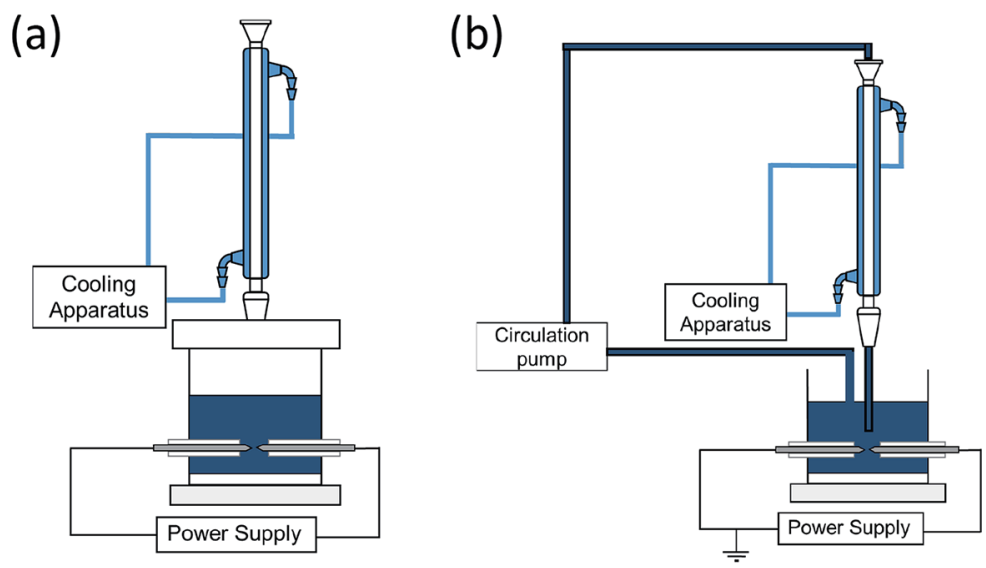

(c)

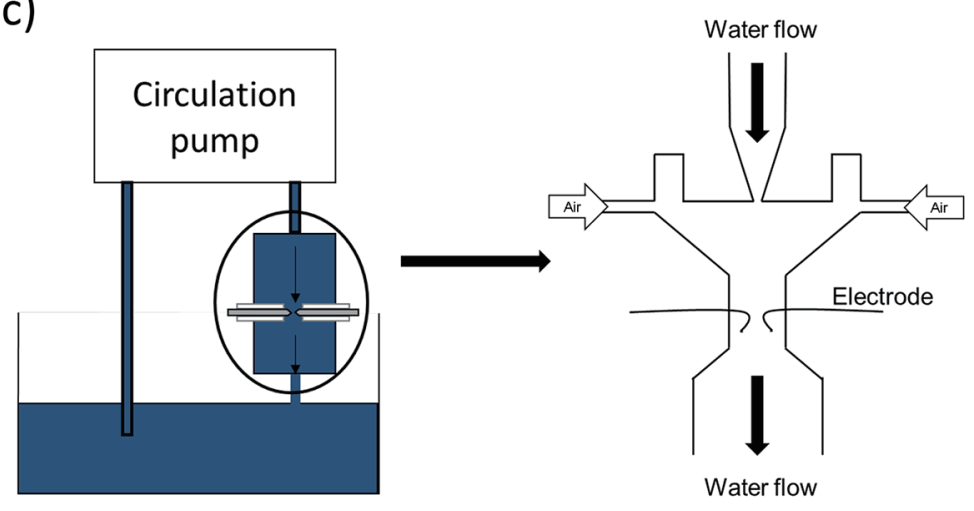

Fig. 1 Experimental setups of (a) in-liquid plasma, (b) in-liquid plasma with cooling and (c) flow plasma for the conversion of MB 
blue decomposition due to lower liquid temperature. Therefore, the conditions of (a) and (b) were set. In the case of (c), the solution flowed from the top to the bottom via a pump, and the flow rate was approximately $9.6 \mathrm{~L} / \mathrm{min}$. By narrowing the flow path, the reactor was depressurized. The atmosphere was sucked in from the side entrance and was ejected between the electrodes together with the solution. We have named (a) and (b) as in-liquid plasma and (c) as flow plasma. The volume of the solution to be treated in each method was $100 \mathrm{~mL}$ for (a), $200 \mathrm{~mL}$ for (b), and $6 \mathrm{~L}$ for (c). The input power from the power source was measured using a wattmeter. The average input power was $730 \mathrm{~W}$ for (a) and (b) and $970 \mathrm{~W}$ for (c).

Spectroscopic measurement systems comprised a photonic multichannel analyzer (PMA-11, HAMAMATSU) were used in the case of (c). Light from plasma was guided through a quartz window to a spectrometer. The quartz window (thickness: $5 \mathrm{~mm}$ ) was mounted at the side of the reactor and fixed using an acrylic cap, while the optical fiber was mounted in front of the quartz window. The measured spectrum ranged from 200 to $950 \mathrm{~nm}$.

UV-vis absorption spectra of the MB solution before and after the plasma treatment were measured using a spectrophotometer in the wavelength range of 200-800 nm. The concentration of MB in the solution was determined from the absorption maximum at $668 \mathrm{~nm}$, which was also employed for the calibration curves.

The conversion percent was calculated as

$$
\operatorname{conv}(\%)=\frac{C_{0}-C}{C_{0}} \times 100
$$

where $C_{0}$ was the initial concentration and $C$ was the final concentration.

Conversely, the energy yield, which indicated the efficiency of the solution decolorization for each discharge method, was defined by the ratio of the amount of $\mathrm{MB}$ removed by the plasma treatment to the input energy. It was calculated as

$$
\text { energy yield }(\mathrm{g} / \mathrm{kWh})=\frac{V(\mathrm{~L}) \times C_{0}(\mathrm{~g} / \mathrm{L}) \times \operatorname{conv}(\%) / 100}{P(\mathrm{~kW}) \times t(\mathrm{~h})}
$$

where $V$ was the MB solution volume and $P$ was the input power of the power supply.

\section{Results and Discussion}

The UV-visible spectra of the MB solution for (a) in-liquid plasma treatment time are shown in Fig. 2 Absorbance (at 293, 609 and $668 \mathrm{~nm}$ ) decreased with plasma treatment time and the solution was decolorized. However, the absorbance near $200 \mathrm{~nm}$ increased with the plasma treatment time. This suggests that low-molecular-weight organic substances are produced by the decomposition
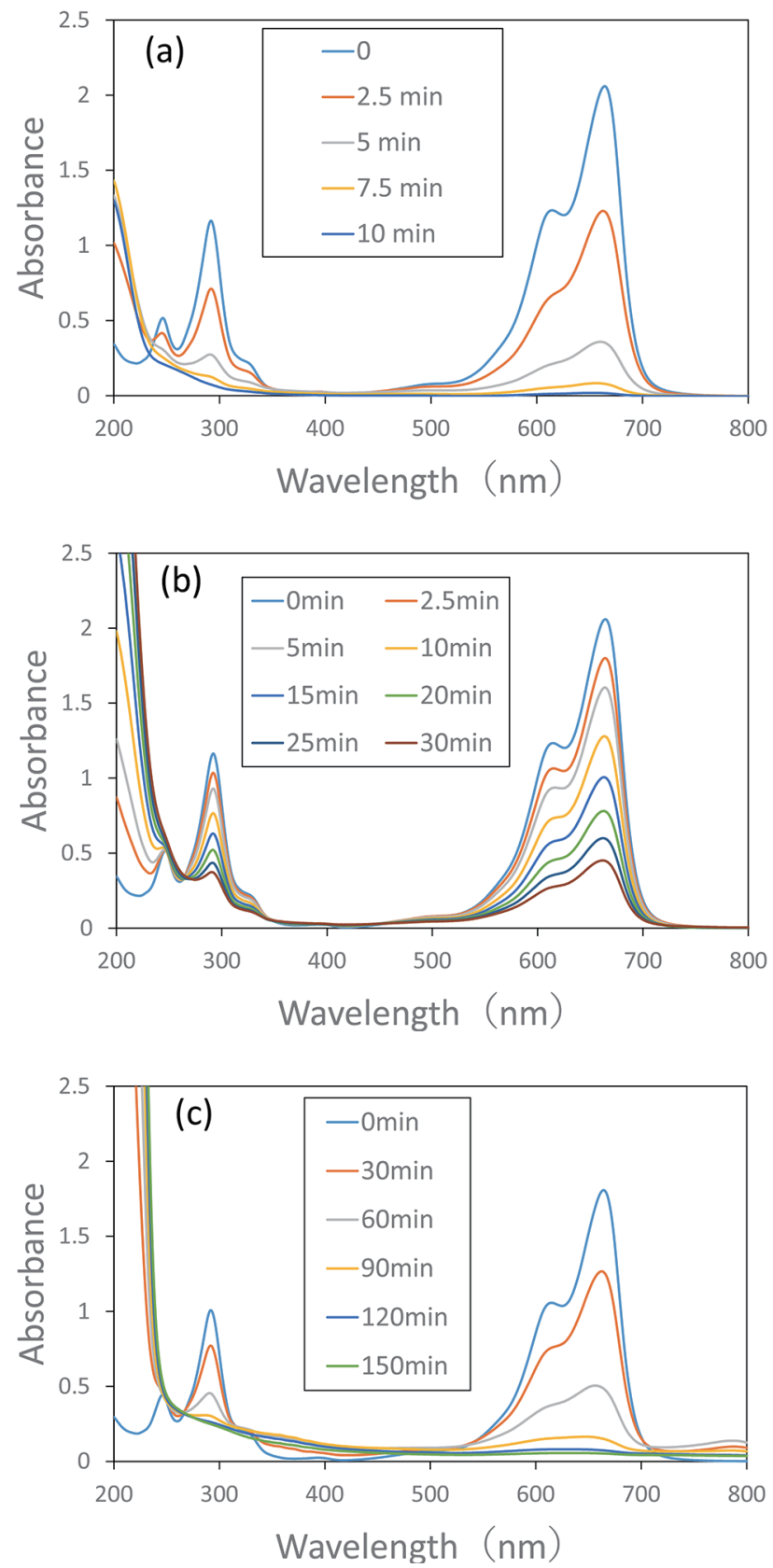

Fig. 2 UV-vis spectra of the MB solution in (a) in-liquid plasma, (b) in-liquid plasma with cooling and (c) flow plasma for each in-liquid plasma treatment time

of methylene blue. The reason why the absorbance near $200 \mathrm{~nm}$ began to decrease when the plasma treatment time was 10 minutes in (a) in-liquid plasma method is thought to be because the low-molecular-weight organic substances was further decomposed into inorganic gas such as carbon dioxide and hydrogen, or water.

Fig. 3 shows the conversion of $\mathrm{MB}$ in each discharge method when the volume to be treated was $100 \mathrm{~mL}$. The assumption that the processing volume and the time taken to convert $\mathrm{MB}$ were proportional was made. The conversion rate of $\mathrm{MB}$ decreased with the lapse of plasma treatment 


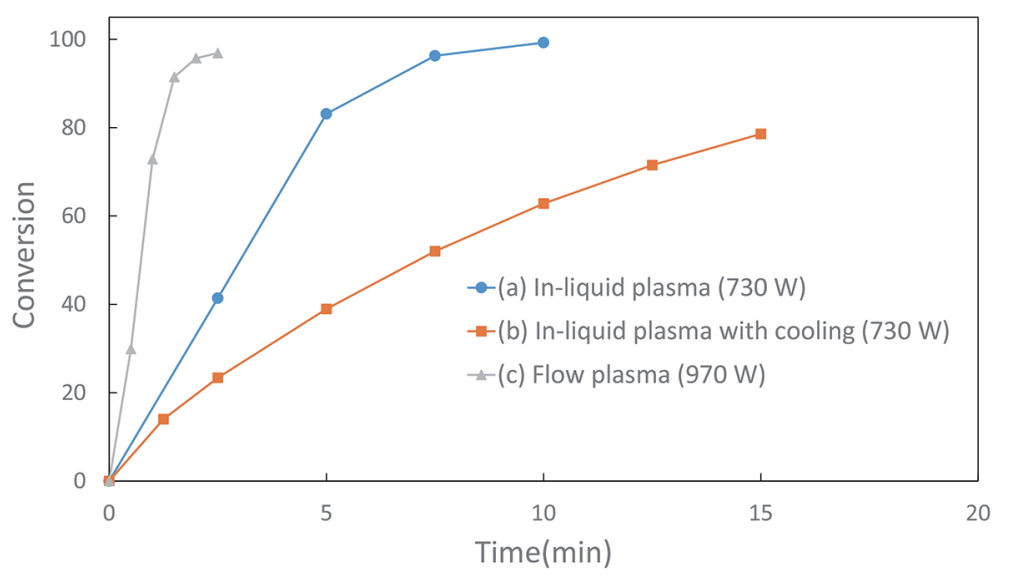

Fig. 3 Conversion of MB in each discharge method when the volume to be treated is $100 \mathrm{~mL}$

time. This was probably because the amount of MB present in the vicinity of the plasma decreased as the concentration of $\mathrm{MB}$ decreased. The temperature of the solution was measured every $1.0 \mathrm{~min}$ after plasma irradiation. In (a), the liquid temperature rose to $100^{\circ} \mathrm{C}$ after $9 \mathrm{~min}$ and remained unchanged thereafter. Conversely, in (b), the temperature rose to $50^{\circ} \mathrm{C}$ after $7.0 \mathrm{~min}$ and remained unchanged thereafter. The fact that the conversion rate of $\mathrm{MB}$ was higher at higher liquid temperatures became clear. A high liquid temperature facilitates the generation of bubbles, and the increase of the conversion efficiency was probably because of the stable generation of the plasma. This effect does not depend on the type of dye, so the same result can be expected with any dye solution.

The emission spectrum from the plasma are shown in Fig. 4. Here, excited species, such as $\mathrm{H}_{\alpha}$ (656 nm), $\mathrm{H}_{\beta}$ (486 nm), Na (589 nm), OH A ${ }^{2} \Sigma^{+-X^{2}} \Pi(0,0)$ band (309 nm), $N_{2}$ (300-400 nm), N (747 nm and $822 \mathrm{~nm}$ ) and $\mathrm{O}$ (777 nm and $845 \mathrm{~nm}$ ) were confirmed. Since nitrogen is not contained in the solution, the emission spectrum of nitrogen means that air is taken in from the outside. As shown in Fig. 2,

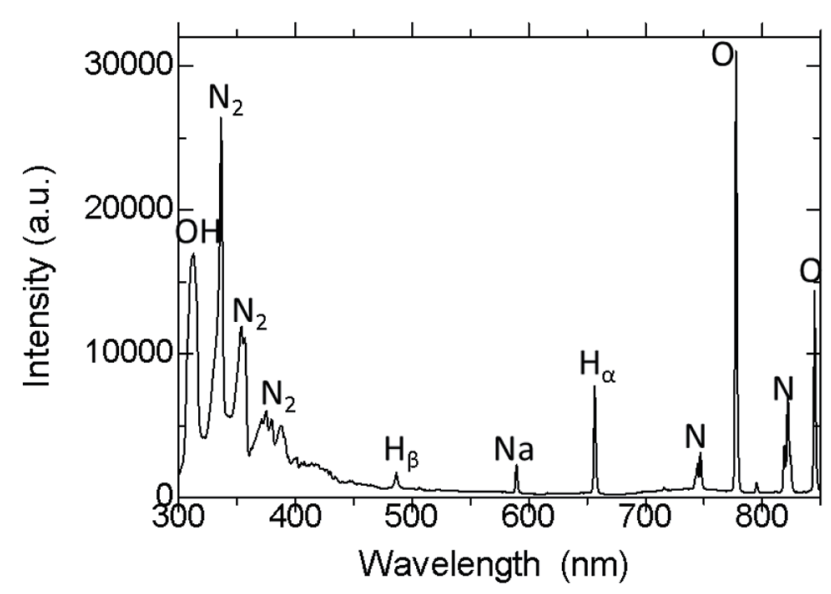

Fig. 4 Emission spectrum of flow plasma
Table 1 Energy yield at 75\% conversion

\begin{tabular}{lc}
\hline \multicolumn{1}{c}{ Plasma type } & $\mathrm{Y}_{75 \%}(\mathrm{~g} / \mathrm{kWh})$ \\
\hline Flow plasma & 0.0439 \\
In-liquid plasma & 0.0137 \\
In-liquid plasma with cooling & 0.0045 \\
\hline
\end{tabular}

in the case of flow plasma, the absorbance near $200 \mathrm{~nm}$ increased even after methylene blue was fully converted. This suggests that nitrogen atoms generated in the plasma became nitrogen oxides and dissolved in water. Nitrogen content is an important factor, as it is limited by wastewater standards. However, depending on the concentration and components, it can be considered as a fertilizer in the agricultural field. These are future research topics.

The energy yield when converting $75 \%$ of $\mathrm{MB}$ is shown in Table 1. The most efficient method for converting $\mathrm{MB}$ was flow plasma. In the flow plasma method, the breakdown voltage was reduced by injecting the solution together with the atmosphere, and the plasma was stably generated over a wide area. In addition, because the effects of highly reactive $\mathrm{OH}$ radicals and ultraviolet rays during light emission were limited to the vicinity of the plasma, the batch method could not efficiently treat the target substance. The high reaction efficiency was probably caused by the forced induction of the solution into the plasma via the pump.

\section{Conclusion}

The MB solution used as a model of dyeing discharge water could be decolorized using plasma. The conversion rate was correlated to the concentration of $\mathrm{MB}$ and decreased with the treatment time. For batch processing, the conversion rate could be increased by keeping the liquid at a high temperature. The absorbance near $200 \mathrm{~nm}$ of the solution increased with the plasma treatment time and began to decrease after the absorbance of methylene blue 
was close to zero. The emission spectrum of flow plasma contains the emission of nitrogen molecules and nitrogen atoms, and the absorbance near $200 \mathrm{~nm}$ was most increased compared to other methods. The flow plasma method was the most energy efficient method, and the energy efficiency was $0.0439 \mathrm{~g} / \mathrm{kWh}$ when $75 \%$ of MB was converted.

\section{Acknowledgment}

The present work was partially supported by JSPS KAKENHI Grant Number 19H02079.

\section{References}

1) Hassan, S. S. M.; Awwad, N. S.; Aboterika, A. H. A., J Hazard Mater, 162, 994-999 (2009)

2) Robinson, T.; McMullan, G.; Marghant, R., Bioresour Technol, 77, 247-255 (2001)

3) Humelnicu, I.; Băiceanu, A.; Ignat, M. E.; Dulman, V., Process Saf Environ Prot, 105, 274-287 (2017)

4) Ara, N. J.; Hasan, M. A.; Rahman, M. A.; Salam, M. A.; Salam, A.; Alam, A. S., Bangladesh Pharm J, 16, 93-98 (2013)

5) Hu, Q. H.; Qiao, S. Z.; Haghseresht, F.; Wilson, M. A.; Lu, G. Q., Ind Eng Chem Res, 45, 733-738 (2006)

6) Rida, K.; Bouraoui, S.; Hadnine, S., Appl Clay Sci, 83-84, 99-105 (2013)

7) Azbar, N.; Yonar, T.; Kestioglu, K., Chemosphere, 55, 35$43(2004)$
8) Alaton, I.; Balcioglu, I. A.; Bahnemann, D., Water Res, 36, 1143-1154 (2002)

9) Jamal, M. A.; Muneer, M.; Iqbal, M., Chem Internatioanl, 1, $12-16(2015)$

10) García, M. C.; Mora, M.; Esquivel, D.; Foster, J. E.; Rodero, A., Chemosphere, 180, 239-246 (2017)

11) Vergara Sanchez, J.; Torres Segundo, C.; Montiel Palacios, E.; Gomez Diaz A.; Reyes Romero, P. G.; Martinez Valencia, H., IEEE Trans Plasma Sci, 45, 479484 (2017)

12) Son, G.; Kim, D.; Lee, J. S.; Kim, H.; Lee, C.; Kim, S. R. et al., J Environ Manage, 206, 77-84 (2018)

13) Khataee, A.; Gholami, P.; Vahid, B., Ultrason Sonochem, 29, 213-225 (2016)

14) Ange, K. T.; Omura, S. N.; Ukasa, S. M.; Oyota, H. T., Production of Hydrogen and Monomer Aromatics by In-liquid Plasma Treatment of Lignin, pp. 171-175 (2018)

15) Nomura, S.; Toyota, H.; Mukasa, S.; Yamashita, H.; Maehara, T:; Kawashima, A., J Appl Phys, 106, 1-4 (2009)

16) Tange, K.; Nomura, S.; Mukasa, S., J. Jpn. Inst. Energy, 98, 265-271 (2019)

17) Tange, K.; Nomura, S.; Mukasa, S., Int J Hydrogen Energy, 44, 23912-23920 (2019)

18) Shiraishi, R.; Nomura, S.; Toyota, H.; Mukasa, S., Int J Hydrogen Energy, 44, 16248-16256 (2019) 